\title{
Environmental Hermenetics: From Cognition to Nature understanding
}

\author{
Nelya Filyanina ${ }^{1}$, Al-Saedi Ahmed ${ }^{2}$, Viktoriya Chitishvili ${ }^{3}$
}

\author{
${ }^{1}$ Doctor of Philosophy Sciences, Associate Professor, Department of Fundamental and language training, National University of Pharmacy, \\ 53, Pushkinska Str., Kharkiv, 61002, Ukraine \\ ORCID identifier: 0000-0002-7439-1986 \\ ${ }^{2}$ National University of Pharmacy, 53, Pushkinska Str., Kharkiv, 61002, Ukraine \\ ORCID identifier: 0000-0003-0907-325X \\ ${ }^{3}$ Teacher of the Foreign Languages Department, National University of Pharmacy, 53, Pushkinska Str., Kharkiv, 61002, Ukraine \\ ORCID identifier: 0000-0003-1713-6011
}

Received: 14 Nov 2020; Received in revised form: 1 Dec 2020; Accepted: 6 Dec 2020; Available online: 15 Dec 2020

(C)2020 The Author(s). Published by Infogain Publication. This is an open access article under the CC BY license

(https://creativecommons.org/licenses/by/4.0/).

\begin{abstract}
The article analyzes the necessity of supplementing the informative-cognitive approach to the mobilization of ecological consciousness by understanding nature. The question of determining the methodological potential of hermeneutics for understanding nature and development of environmental hermeneutics as a special field of research is considered.
\end{abstract}

Keywords-Hermeneutics, environmental hermeneutics, nature, environment, cultural dialogue about nature, ecological crisis.

\section{MAIN PART}

To persuade politicians, business and the general public in the reality of global, regional and local environmental crises and related hazards, experts in scientific and environmental environments often appeal to objective facts that establish the levels of pollution of the air, water, soil, and loss of their fertility, an increase in the list of species of plants and animals that are extinct or endangered. For instance, since 2003, the United Nations Environment Program (UNEP) has published UNEP annual reports (UNEP Year Book) on the most pressing issues of the global environment and global environmental policy. The level of knowledge about the dangerous environment and risks to human life provided by different sources is much more accessible to the public than in the previous decades due to the development of the Internet and social networks. Nevertheless, despite the considerable efforts of the global community, national governments and the public, numerous facts do not turn into a holistic knowledge system, and knowledge is not directly converted into environmental awareness, environmental responsibility and active action in the field of environmental protection. This testifies to the lack of an informative-cognitive approach to the mobilization of ecological consciousness.
M. M. Kyseliov and F. M. Kanak say: "Knowledge of a diverse ecological empiric still needs to be further understood, organically involved into a single conceptual system. This procedure is extremely important and at the same time complicated in the process of implementation."1

Scientists, philosophers, culturologists, and politicians increasingly say about the need for a deep understanding of nature as a condition for overcoming the environmental crisis. After all, in order to understand what our actions are wrong and destructive to the nature, one needs to understand the nature itself. Understanding nature is also necessary for a deeper self-awareness of the place of man in the world and his introduction into nature.

\footnotetext{
${ }^{1}$ Kanak F.M., Kiselyov M.M.National being among ecological realities. (Kyiv: Tandem, 2000), 278, "Znannya bahatomanitnoyi ekolohichnoyi empiriyi treba shche dovesty do rozuminnya, orhanichno pov'yazaty yiyi v yedynu kontseptual'nu systemu. Zaznachena protsedura ye nadzvychayno vazhlyvoyu y vodnochas skladnoyu v protsesi realizatsiyi."
} 
Knowledge of nature can not be limited solely by the scientific knowledge and its description by the language of science. As H.-G. Gadamer says:" Thus the sun has not ceased to set for us, even though the Copernican explanation of the universe has become part of our knowledge. ... we cannot try to supersede or refute natural appearances by viewing things through the "eyes" of scientific understanding. ... what we see with our eyes has genuine reality for us, but also because the truth that science states is itself relative to a particular world orientation and cannot at all claim to be the whole."

Therefore, when discussing contemporary ecological problems and ways of their solution, the question of determining the methodological potential of hermeneutics is raised.

Today, there appears an urgent need to supplement the rational cognition of the laws of the functioning nature with the comprehension of the meanings hidden in it and their interpretation (by Hans Blumenberg), which should contribute to a deeper understanding of both the inner world of man and the world in which he lives. One way of such an understanding of nature can be "reading" nature, like reading a book. ${ }^{3}$

A. Yermolenko characterizes the desire to understand nature as a hermeneutical-ecological utopia, in which another attempt is made to overcome the Faustian position, the New European rationalist attitude toward nature as an object, on the one hand, and its comprehension as a subject or partner, that is, as "the carrier of immanent meanings that need to be deciphered and understood", on the other ${ }^{4}$.

The aim of the article is to analyze the concept of environmental hermeneutics and its potential in overcom-

2 GadamerH.-G.,Truth and method, trans.B.N. Bessonov (Moscow: Progress, 1988), 519, "Solntse zakhodit dlya nas poprezhnemu, khotya my i znakomy s kopernikanskoy kartinoy mira. ... my ne mozhem snyat' ili oprovergnut' etu prirodnuyu vidimost', vzglyanuv na zakat «glazami» etogo nauchnogo rassudka. ... vidimost' predstavlyayetsya dlya nas nastoyashchey real'nost'yu, no takzhe i potomu, chto istina, kotoruyu soobshchayet nam nauka, sama sootnesena s opredelennym otnosheniyem k miru i nikoim obrazom ne mozhet pretendovat' na to, chtoby byt' vsey istinoy v tselom."

${ }^{3}$ Bogachev A., "Hermeneutics Philosophical."In The Philosophical Encyclopedic Dictionary, edited by V. I. Shynkaruk, 115 - 16. Kyiv: Abris, 2002, "prochytannya".

${ }^{4}$ Yermolenko A. M.,Social ethics and ecology. Human dignity is the reverence of nature (Kyiv: Libra, 2010), 194, "nosiya imanentnykh smysliv, yaki treba rozshyfruvaty ta zrozumity." ing the ecological crisis. We should consider the essence of the hermeneutic approach and the possibilities of its application in the field of interpretation of nature, which will reveal those specific aspects of the system "mannature" where a hermeneutic approach can be applied.

First of all, it is necessary to clarify the question of how lawfully the hermeneutic approach can be applied, that traditionally belongs to the methodology of the humanities, for the interpretation and understanding of nature, which is the object of natural science. At the same time, there arise questions about the limits of the use of the hermeneutic method and its productivity, as well as the principles of the establishment of environmental hermeneutics.

Hermeneutics has traditionally been defined as the art of interpreting texts and other manifestations of thought. The ultimate embodiment of the text are books, the most prominent of which is the Bible. Philosophical hermeneutics was formed during the study of the problem of interpretation in two aspects: firstly, solving the problem of multivalued characters; and secondly, finding the answer to the question of the correlation between the text and being. Above all, universal hermeneutics posed the task of determining the meaning of any text, depending on the understanding of the author's plan, and not the connection between the text and the reader. However, reading as an interaction between the text and the interpreter is the basis of any understanding 5 .

Until the beginning of the twentieth century the problem of hermeneutics as a comprehension of the text and the problem of philosophy were interpreted separately. From the beginning of the twentieth century the term "hermeneutics" and "hermeneutic approach" have begun to be related to the philosophical conception of the very phenomenon of understanding, and hence the whole methodology and practice of humanitarian and historical disciplines. In the historical science of Wilhelm Dilthey (18331911), hermeneutics as an art of interpreting of written monuments (life manifestations) is included in the process of cognition of the logic and methodology of the humanities and proclaimed a connecting link between philosophy and historical disciplines, the main component of the foundations of the spirit sciences. Thus, in the traditional

${ }^{5}$ Blumenberg, Hans, World as a Book. Translated by V. Yermolenko Kyiv: Libra, 2005. 
sense, hermeneutics is an epistemological foundation and methodology of the humanities ${ }^{6}$.

According to V. Kebuladze, philosophical hermeneutics "problematizes the claim of phenomenology to the creation of a universal scientific method, because, on the one hand, the possibility of a universal scientific method is very problematic in view of the fundamental differences of the natural type of cognition from the humanitarian one, on the other, the truth can be given to us not only via scientific cognition. Thus, Gadamer claims not only the creation of a universal scientific method of truth cognition, but also the creation of a total comprehensive strategy of understanding that can be realized in all spheres of human life, and not purely in science. At the same time, the application of such a strategy ensures self-declaration of the truth of human existence and the existence of the world."7 According to V.Kebuladze, hermeneutics claims to create "a general conception of understanding as a fundamental attitude to oneself and to the world, an attitude that is embodied not only in scientific knowledge, but in all forms of human experience, and above all in artistic creativity and historical experience." $"$

The German philosopher Hans Blumenberg notes that "hermeneutics is that not simply must have its meaning and store it through all times, and that it is through its

${ }^{6}$ Kosharniy S. O. "Hermeneutics.” In The Philosophical Encyclopedic Dictionary, edited by V. I. Shynkaruk, (Kyiv: Abris, 2002), 115.

${ }^{7}$ Kebuladze V., Phenomenology and hermeneutics in the structure of philosophical education (Philosophical thought, No. 5, 2013), 53, "problematyzuye pretenziyu fenomenolohiyi na stvorennya universal'noho naukovoho metodu, adzhe, z odnoho boku, mozhlyvist' universal'noho naukovoho metodu vel'my problematychna $z$ ohlyadu na fundamental'ni vidminnosti pryrodoznavchoho vydu piznannya vid humanitarnoho, $\mathrm{z}$ inshoho, istyna mozhe buty dana nam ne lyshe $\mathrm{v}$ naukovomu piznanni. Takym chynom, Hadamer pretenduye ne prosto na tvorennya universal'noho naukovoho metodu piznannya istyny, a y na stvorennya total'noyi stratehiyi rozuminnya, yaka mozhe buty zrealizovana $\mathrm{v}$ usikh tsarynakh lyuds'koyi zhyttyediyal'nosti, a ne suto v nautsi. Pry ts'omu zastosuvannya takoyi stratehiyi zabezpechuye samovyyavlennya istyny lyuds'koho buttya i buttya svitu."

${ }^{8}$ Kebuladze V., Phenomenology and hermeneutics in the structure of philosophical education, 53, "zahal'noyi kontseptsiyi rozuminnya yak fundamental'noho stavlennya do sebe y do svitu, stavlennya, shcho vtilyuyet'sya ne til'ky v naukovomu piznanni, ale $\mathrm{u}$ vsikh formakh lyuds'koho dosvidu, a nasampered $\mathrm{u}$ khudozhniy tvorchosti ta v istorychnomu dosvidi." multiple meanings includes interpretation in its meaning," and by this giving its subject the opportunity to enrich itself with new interpretations. ${ }^{9}$ From this perspective, not only books but nature can be considered as an object of hermeneutics.

In the monograph "Social Ethics and Ecology" (2010) A. Yermolenko explores the potential of using hermeneutic methods to understand both the causes and ways of overcoming environmental crises. The interest in hermeneutic methods for explaining nature and the environment allows us even to speak of ecological hermeneutics as a separate study direction. ${ }^{10}$ Moreover, the understanding of nature, which must be based on sensitivity to history, culture, and the narrative, is defined as a fundamental task of hermeneutics. Hermeneutical research is also actualized in connection with the need to find a public consensus on understanding nature as different people perceive and interpret nature in different ways, and therefore they differently determine their relations with it, the place of nature in the human world, the conditions and ways to solve a lot of problems that arise between man and nature.

In the preface to the book "Interpreting Nature: The Emerging Field of Environmental Hermeneutics" several approaches to the definition of environmental hermeneutics are presented: ${ }^{11}$

1) environmental hermeneutics as an expanded interpretation of any environment (natural, artificial,

${ }^{9}$ Blumenberg, Hans. World as a Book. Translated by V. Yermolenko (Kyiv: Libra, 2005, 38.

${ }^{10}$ Yermolenko A. M.Social ethics and ecology. Human dignity is the reverence of nature. Kyiv: Libra, 2010;Exploring Ecological Hermeneutics, edited by Norman C. Habel and Peter Trudinger.

Atlanta:Society of Biblical Literature.

http://books.google.com.ua/books?id=fmskY3gb5g8C\&pg=PA1

\&lpg=PA1\&dq=ecological + hermeneutics $\&$ source $=$ bl \&ots $=6 \mathrm{bSd}$ qnlbk \&sig=leY2mWJ VjODn2GBfaxzIHz1GAk\&hl=uk\&sa=X \&ei=RvZYU4r4M6jU4QS-

$\underline{\mathrm{uIBQ} \& \mathrm{ved}=0 \mathrm{CIsBEOgBM} \text { Ag\# } \mathrm{v}=\text { onepage } \& \mathrm{q}=\text { ecological } \% 20 \mathrm{her}}$ meneutics\&f=false; Interpreting Nature: The Emerging Field of Environmental Hermeneutics, edited by Forrest Clingerman, Brian Treanor, Martin Drenthen, and David Utsler. Fordham University Press: 2013.

http://environmentalhermeneutics.blogspot.com/; Keller David. R. "Ecological Hermeneutics." Philosophy and the Environment, https://www.bu.edu/wcp/Papers/Envi/EnviKell.htm ${ }^{11}$ Interpreting Nature: The Emerging Field of Environmental Hermeneutics, edited by Forrest Clingerman, Brian Treanor, Martin Drenthen, and David Utsler. Fordham University Press: 2013. http://environmentalhermeneutics.blogspot.com/ 
cultural, etc.). In this very broad and abstract defining, hermeneutics acts as an interpretive activity in general irrespective of the subject of environmental interpretation (native inhabitant, tourist, scientistnaturalist, artist, architect, constructor, etc.);

2) environmental hermeneutics as an interpretation of the immediate encounter of a person with a particular environment or human condition within a specific environment. This type of interpretation involves deepening into the area with which we interact directly, where we are as researchers, or encounter when reading the text about this area. This type of interpretation takes into account information signs of nature or historical places and is practiced, for instance, in a form of instructions from experts of the place for visitors, but it does not exclude the direct and interpretive activity of a visitor;

3) environmental hermeneutics as an essay on nature ("nature writing"). Typical examples of such a writing include the literary heritage of Aldo Leopold, George Moore and others. This type of environmental hermeneutics appears as a personalized version of its previous variant, since it implies, on the one hand, the author's, subjective interpretation of nature, and on the other - an interpretive activity of a reader, his understanding and experience of reading. This type of hermeneutics is a representation of how nature can be "captured" in the text and how it can be experienced through the text;

4) environmental hermeneutics as a certain summary, a list of approaches to various disciplines to nature and the environment in general. Correspondently, environmental hermeneutics appears a priori as a reign of interdisciplinary research, where each of the disciplines (ecology, geography, cultural studies, literary criticism, etc.) provides its own interpretation of nature in accordance with its inner logic. Environmental hermeneutics has the role of a critical intermediary between different disciplinary interpretations in order to develop a more holistic and clear understanding of the environment and nature;

5) Environmental hermeneutics is considered as a philosophical position that allows us to understand how the inevitability, which Gadamer calls "our hermeneutic consciousness," reveals our links with the environment. Such an understanding of environmental hermeneutics not only provides a technique for interpreting the environment, but also im- merses it into the corresponding ontological context necessary for such an interpretation.

At the same time, the authors of the book note that the given list of definitions is not exhaustive and does not exclude other approaches to the understanding and definition of environmental hermeneutics. In particular, religious, theological, and various scientific studies may offer additional approaches to the definition of environmental hermeneutics. Meanwhile, an important feature of environmental hermeneutics, regardless of a specific definition, is its focus on the dialogue between man and the environment. ${ }^{12}$ Therefore, studies on environmental hermeneutics should take into account the specific experience of staying in the environment and its experience; they should rely on specific studies (case studies) of human interaction with the environment.

Environmental hermeneutics as an interpretation of the nature and interaction of man with the environment is considered as the basis of eco-philosophy, since it provides the opportunity to reflect on the experience of human being in a certain environment and its interpretations, emphasizing the danger of ignoring the surrounding world of a person. Environmental hermeneutics also pays a lot of attention to so-called "conflict interpretations" that arise during inter-subject "collisions" 13 with various materials, emotions, and rational concepts. Therefore, it is interested in an indirect experience, which allows developing a consolidated vision of the problems that arise because of human interaction with the environment.

Distinguishing environmental hermeneutics as an independent field of research, it is important to understand its connections with philosophical hermeneutics, the possibility of using the methods of philosophical hermeneutics, on the one hand, and their modifications in accordance with the specifics of the object of research and interpretation, on the other. There arises the question as to how philosophical hermeneutics as an art of text interpreting can be applied to the interpretation of nature. In the analysis of the relation of philosophical and environmental hermeneutics, several aspects can be distinguished.

One of them concerns the definition of nature in hermeneutic research.

\footnotetext{
12 "sfokusovanist' na dialozi mizh lyudynoyu ta navkolyshnim seredovyshchem, dovkillyam."

13 "zitknen"”
} 
As we know, philosophical hermeneutics deals with different ways of interaction with the world. Nature is a part of this world. Since today it is increasingly difficult to find a plot of virgin nature that is not subjected to human intervention, environmental hermeneutics refers to the various contexts of nature and the environment understanding, not limited to wild, untouched nature.

Thus, the authors of the mentioned book, "Interpreting Nature: The Emerging Field of Environmental Hermeneutics", turn to a broader understanding of the environment, that encompasses both the natural and sociocultural environment that has undergone various human influences and transformations, including those constructed by means of architecture. In addition, environmental hermeneutics believes that it is expedient to focus on and analyze the virtual world, which is rapidly becoming a part of human existence, often replacing the real world. Because of such a broad understanding of the environment, there are significant difficulties in determining the nature and the natural environment as an open space for productive dialogue and understanding. After all, according to H.G. Gadamer, the language is the medium, "where the process of mutual agreement between the partners takes place and mutual understanding is reached on the very cause." 14 H.-G. Gadamer writes: "...Language is the universal medium in which understanding occurs. Understanding occurs in interpreting." 15 H.-G. Gadamer attached great importance to the interpretation and understanding of the world, which largely depends on the definition of the latter as the "medium" in which a person lives, as well as the influences that the environment has on a person and his way of life. Man is not independent of the world. H.-G. Gadamer says:"Thus the concept of environment is originally a social concept that tries to express the individual's dependence on society - i.e., it is related only to man. In a broad sense, however, this concept can be used to comprehend all the conditions on which a living creature depends. But it is thus clear that man, unlike all other living creatures, has a "world," for other creatures do not in the same sense have a relationship to the world, but are, as it

14 Gadamer H.-G. Truth and method. Translated by B.N. Bessonov (Moscow: Progress, 1988), 447, "gde proiskhodit protsess vzaimnogo dogovora sobesednikov i dostigayetsya vzaimoponimaniye po povodu samogo dela."

${ }^{15}$ Gadamer H.-G. Truth and method, 452, "yazyk, - eto universal'naya sreda, v kotoroy osushchestvlyayetsya imenno ponimaniye. Sposobom etogo osushchestvleniya yavlyayetsya tolkovaniye." were, embedded (eingelassen) in their environment." 16 Thus, we see that the inclusion of nature in the sphere of interpretation and understanding does not contradict hermeneutics, and therefore it legitimizes discussions on environmental hermeneutics.

In the case of environmental hermeneutics, the authors of "Interpreting Nature: The Emerging Field of Environmental Hermeneutics" point out; the dialogue may seem problematic, as the other side of the dialogue - nature, the environment - is devoid of verbal means of dialogue. However, according to H.-G. Gadamer, mutual understanding does not require any special tools in the proper sense of the word: "It is a life process in which a community of life is lived out." ${ }^{17}$ Correspondently, we can say about our understanding of nature, but we can hardly speak about mutual understanding.

Because of this, environmental hermeneutics has to pay considerable attention to the methods of mediation, through which people try to provide "language to nature" via its description and interpretation, spreading this language in society. Therefore, environmental hermeneutics is actually a dialogue about nature in culture, or a cultural dialogue about nature. And it is via this dialogue that the experience of expanding the horizon of "our analysis of the hermeneutic experience" is being realized. ${ }^{18}$ It seems that the question of the possibility of identifying nature as a participant in the dialogue in the context of environmental hermeneutics is in the same problematic path as the question of the conceptualization of environmental ethics and the inclusion of nature in the sphere of human morality. In particular, this is stated in the study of A. Yermolenko, where he aspires to find out "how much

\footnotetext{
${ }^{16}$ Gadamer H.-G. Truth and method, 513;"'Sootvetstvenno, ponyatiye okruzhayushchego mira bylo snachala ponyatiyem sotsial'nym, chto svidetel'stvovalo o zavisimosti otdel'nogo cheloveka ot obshchestvennogo mira, to yest' ponyatiyem, kotoroye sootnositsya isklyuchitel'no s chelovekom. Odnako v boleye shirokom smysle eto ponyatiye mozhet rasprostranyat'sya na vse zhivoye. V takom sluchaye ono summiruyet usloviya, ot kotorykh zavisit yeye sushchestvovaniye. Odnako etot mir otnositsya tol'ko $\mathrm{k}$ cheloveku, poskol'ku ostal'nyye zhivyye sushchestva "ne znayut otnosheniya k miru v chelovecheskom smysle, no kak by vpushcheny (eingelassen) v okruzhayushchiy mir."

17 Gadamer H.-G. Truth and method, 516,"Eto zhiznennyy protsess, v kotorom prozhivayetsya sama zhizn' chelovecheskogo soobshchestva".

${ }^{18}$ Gadamer H.-G. Truth and method, 515,"ekologicheskaya germenevtika na samom dele yavlyayetsya dialogom o prirode $\mathrm{v}$ kul'ture, ili kul'turnym dialogom o prirode."
} 
we can extend the principles of communicative and discursive ethics and nature, taking into account the fact that nature in particular and its individual fragments can not be equal subjects of a dialogue with a man, because the relationships of man with nature are not relationships of reciprocity, they are asymmetric relations." ${ }^{19}$ Analyzing the various views on this problem, A. Yermolenko expresses the opinion that the representation of nature in the system of ethics can be justified on the basis of the principle of "universal reciprocity", according to which the moral attitude of man to nature, as well asits institutionalization are the same stages, as well as the moral consciousness of the person himself, when, in the end, the person comes to perceive nature as an equal subject of communication and discourse, to whose voice man must listen to. The conclusion is that a person must develop in himself "the ability to hear the voice of nature and understand its meanings, which, in turn, is achieved by knowing the laws of its existence and development." ${ }^{20}$ The basis of the "modern Valuable-Semantic Universe must become the universe of discourse, where nature appears not only as its subject, but indirectly as an equal quasi-party." 21 Thus, "speaking via human communication, nature reaches its integrity through the minds of people, and makes it possible to perceive itself as such integrity, and as integrity expresses itself as a mind that is no longer merely an instrumental mind, but a logos. And logos is realized via word, speech, and argumentation." 22

On the other hand, as follows from "Truth and Method", the concept of language does not only appeal to the human language, but also appeals to all forms of speech, which are inherent in things. H.-G. Gadamer suggests an opportunity to speak "not only of a language of art

\footnotetext{
${ }^{19}$ Yermolenko A. M.Social ethics and ecology. Human dignity is the reverence of nature (Kyiv: Libra, 2010), 240, "naskil'ky my mozhemo poshyryty pryntsypy komunikatyvnoyi ta dyskursyvnoyi etyky i na pryrodu, vrakhovuyuchy toy fakt, shcho pryroda zokrema i okremi yiyi frahmenty ne mozhut' buty rivnopravnymy sub"yektamy dialohu z lyudynoyu, adzhe vidnosyny lyudyny $\mathrm{z}$ pryrodoyu - tse ne vidnosyny vzayemnosti, tse asymetrychni vidnosyny."

${ }^{20}$ Yermolenko A. M.Social ethics and ecology. Human dignity is the reverence of nature, 244, "universal'noyi vzayemnosti."

${ }^{21}$ Yermolenko A. M.Social ethics and ecology. Human dignity is the reverence of nature, 251 ;

22 Yermolenko A. M.Social ethics and ecology. Human dignity is the reverence of nature, 253;
}

but also of a language of nature - in short, of any language those things have." 23

Since philosophical hermeneutics deals mainly with human language and human discourse, the language can also appeal to the presentation of both man himself and others? Accordingly for environmental hermeneutics, hermeneutics is indirectly wherever the study of the content goes up over the binary or dichotomy "man - nature", which was "darkened" by previous forms of ecological thinking, and from the point of view of which the ecological philosophy could not completely free itself. ${ }^{24}$

Due to the rather broad understanding of the meaning of the concept "environment", environmental hermeneutics can not ignore the analysis of the dichotomy "nature-culture", which reflects the relation of the primordial nature and the transformed ("cultivated") nature that appears in the form of the environment as a result of human activity, and, accordingly, dichotomy "nature centrism - anthropocentrism", which, in its turn, represents its attitude to the natural world and the understanding of its place in it.

Besides, environmental hermeneutics draws attention to the fact that understanding the environment is always a contextual understanding. ${ }^{25}$ It manifests itself not in the abstract space but in its own specific localization and necessarily in a certain cultural environment, whichbelongs to this particular place, this locality. Therefore, without active discussions about the meaning of the environment, that is, without the living cultural and moral traditions, there can be no moral sense, and the moral culture in its turn transforms into fossil fate.

J. van Buren defines hermeneutics as a philosophical study of the most common aspects of interpretation, or actions of people during the interpretation. These aspects include intentionality, being-in-the-world, language, sociality, time, and narrative. Environmental hermeneutics first studies sense or meaning of the environment for those who perceive it, and thus, significantly differs from the natural

\footnotetext{
${ }^{23}$ Gadamer H.-G. Truth and method, 549,"Ne tol'ko o yazyke iskusstva, a takzhe i o yazyke prirody, ob opredelennom yazyke, na kotorom govoryat veshchi."

${ }^{24}$ Interpreting Nature: The Emerging Field of Environmental Hermeneutics, (Fordham University Press, 2013),http://environmentalhermeneutics.bl ogspot.com/

${ }^{25}$ Interpreting Nature: The Emerging Field of Environmental Hermeneutics, (Fordham University Press, 2013).
} 
sciences, which focus mainly on the biophysical aspects of the environment. Correspondently, for the environmental hermeneutics, the environment acts both as an object of interpretation and as a narrative. ${ }^{26}$

The method of interpreting one or another environment determines the form of human self-identification in one or another narrative. For instance, in different interpretations of a forest, a person can identify himself as a forestry or timber purchaser, a logger, in others - either as a resident whose life is closely connected to the forest, or a wildlife conqueror, a hunter, a tourist, a nature protector, etc.

According to H.-G. Gadamer, "in every worldview the existence of the world-in-itself is intended. Linguistically schematized experience refers to the whole. The multiplicity of these worldviews does not involve any relativization of the "world." Rather, the world is not different from the views in which it presents itself." 27 Thus, environmental hermeneutics helps take into account various content when solving complex problems.

Thus, environmental hermeneutics can be used to solve complex environmental problems and serve as a methodological basis for seeking consensus in decisionmaking, environmental education and upbringing.

Thus, we can conclude that an informativecognitive approach to the mobilization of environmental consciousness should be complemented by an understanding of nature for a deeper self-awareness of the place of man in the world and his introduction into nature and the conditions for overcoming the ecological crisis. Therefore, when discussing contemporary ecological problems and ways of their solution, raises the question of the determination of the methodological potential of hermeneutics and the establishment of environmental hermeneutics as a special field of research.

The literature presents a wide range of definitions of environmental hermeneutics, but the characteristic fea-

\footnotetext{
${ }^{26}$ Van Buren, J.,Critical Environmental Hermeneutics, (Environmental Ethics 17, Fall 1995), http://origin.web.fordham.edu/images/academics/programs/envir onmental_studies/vanburenenvethics-del.pdf

${ }^{27}$ Gadamer H.-G. Truth and method, 513, "Ved' vo vsyakom mirovozzrenii imeyetsya $\mathrm{v}$ vidu v-sebe-bytiye-mira. Mir yest' to tseloye, s kotorym sootnesen skhematizirovannyy yazykom opyt. Mnogoobraziye podobnykh mirovozzreniy sovsem ne oznachayet relyativizatsii «mira». Skoreye to, chto yest' mir, neotdelimo ot tekh «vidov», v kotorykh on yavlyayetsya."
}

ture of environmental hermeneutics is its focus on the dialogue between man and the environment.

An important task of hermeneutic research is to determine nature. Due to a broad understanding of the environment, there are significant difficulties in determining the nature and the natural environment as an open space for productive dialogue and understanding. Environmental hermeneutics is a dialogue about nature in culture, or cultural dialogue about nature.

The question of the possibility of defining nature as a participant in the dialogue to the context of environmental hermeneutics is in the same problem way as the question of the conceptualization of environmental ethics and the inclusion of nature in the sphere of human morality.

\section{CONCLUSION}

Thus, we can conclude that the application of the hermeneutic method seems quite legitimate, because environmental issues, which relate not only to nature but also to the environment, where human life and activity, contain elements of nature and culture (transformative human activity), which is the scope of humanities research. It is the hermeneutic method that is used to interpret nature and natural and cultural heritage, integrates natural science and humanities knowledge in education and Eco-education as components of the system of continuous education and justifies the reluctance to expand competent expert thought in order to influence political decisions in the field of conservation of natural and cultural heritage. The way we interpret nature depends on its understanding, as well as the planning of activities related to the impact on the natural environment.

Thus, ecological hermeneutics attracts more and more attention in view of defining the limits and possibilities of philosophical hermeneutics and analysis of trends to expand its methodological potential, as well as the need to attract new approaches to solving modern ecological and anthropological problems. This is due to a very diverse range of definitions of ecological hermeneutics.

\section{REFERENCES}

[1] Bogachev A. "Hermeneutics Philosophical." In The Philosophical Encyclopedic Dictionary, edited by V. I. Shynkaruk, 115 - 16. Kyiv: Abris, 2002.

[2] Blumenberg, Hans. World as a Book. Translated by V. Yermolenko. Kyiv: Libra, 2005.

[3] Gadamer H.-G. Truth and method. Translated by B.N. Bessonov. Moscow: Progress, 1988. 
[4] Yermolenko A. M.Social ethics and ecology. Human dignity is the reverence of nature. Kyiv: Libra, 2010.

[5] Kebuladze V. "Phenomenology and hermeneutics in the structure of philosophical education." Philosophical thought, No. 5, 2013.

[6] Kanak F. M. and Kiselyov M.M.National being among ecological realities. Kyiv: Tandem, 2000.

[7] Kosharniy S. O.“ Hermeneutics.” In The Philosophical Encyclopedic Dictionary, edited by V. I. Shynkaruk, 114 - 15. Kyiv: Abris, 2002.

[8] Van Buren, J. "Critical Environmental Hermeneutics.” Environmental Ethics17, (Fall 1995): 259-75. http://origin.web.fordham.edu/images/academics/programs/ environmental_studies/vanburenenvethics-del.pdf

[9] Exploring Ecological Hermeneutics,edited by Norman C. Habel and Peter Trudinger. Atlanta:Society of Biblical Literature.

http://books.google.com.ua/books?id=fmskY3gb5g8C\&pg $=\mathrm{PA} 1 \& \mathrm{lpg}=\mathrm{PA} 1 \& \mathrm{dq}=$ ecological+hermeneutics \&source=bl \&ots=6bSdqnlbk_\&sig=leY2mWJ_VjODn2GBfaxzIHz1G $\underline{A k \& h l=u k \& s a=X \& e i=R v Z Y U 4 r 4 M 6 j U 4 Q S-}$ uIBQ\&ved=0CIsBEOgBMAg\#v=onepage $\& \mathrm{q}=$ =cological $\%$ 20hermeneutics\&f=false

[10] Interpreting Nature: The Emerging Field of Environmental Hermeneutics, edited by Forrest Clingerman, Brian Treanor, Martin Drenthen, and David Utsler. Fordham University Press: 2013.

http://environmentalhermeneutics.blogspot.com/

[11] Keller David. R. "Ecological Hermeneutics." Philosophy and the Environment. https://www.bu.edu/wcp/Papers/Envi/EnviKell.htm 